\title{
FEDERAL ESTATE TAX: EFFECT OF SUBSEQUENT EVENTS ON THE VALUATION OF CLAIMS AGAINST THE ESTATE
}

\begin{abstract}
A i 960 case, Commissioner v. Estate of Carlton A. Shively, ${ }^{1}$ threatens to interject an element of doubt into the amount of tax payable by an estate against which claims have been asserted. The claim in the Shively case arose out of a separation agreement, incorporated into a subsequent divorce decree, under which the husband $(H)$ was to make weekly payments of $\$ 40$ to his wife $(W)$ until her death or re-marriage. ${ }^{2} H$ died in July I952 and his executor continued the payments until $W$ 's re-marriage in June 1953. In $H$ 's estate tax return, filed in July I953, the executor sought to deduct the actuarial value of $W$ 's right to future payments at the time of $H$ 's death as a claim against the estate. ${ }^{3}$ The Commissioner, however, limited the deduction to the total amount actually paid $W$ before her re-marriage. On appeal from an order of the Tax Court allowing the larger deduction claimed by the estate, ${ }^{4}$ the Court of Appeals for the Second Circuit reinstated the Commissioner's determination, holding that consideration should be given to events occurring before the estate tax return is filed in determining the amount of deductible claims. ${ }^{5}$
\end{abstract}

The 1954 Code allows a deduction for claims against the estate, ${ }^{6}$ but contains no express provision concerning their valuation. The Regulations also provide little aid in valuing claims that may be affected by later events. ${ }^{7}$ The Shively case is illustrative of the resulting inconsistency in the decisions.

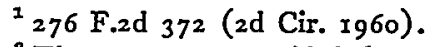

${ }^{2}$ The agreement provided that upon the husband's death subsequent payments would be a charge on his estate.

${ }^{3}$ It is well settled that where the divorce court has power to decree a settlement of property rights or to vary the terms of a separation agreement, any payments made pursuant to such settlement or agreement incorporated into the divorce decree are fully deductible. Such payments do not require "full and adequate consideration" because they are deemed to be a claim founded upon the decree instead of upon the prior "promise or agreement" between the parties. See Commissiouer v. Estate of Watson, 216 F.2d 94I (2d Cir. 1954); Commissioner v. Maresi, I56 F.2d 929 (2d Cir. 1946); Commissioner v. State Street Trust Co., I28 F.2d 618 (1st Cir. 1942).

Estate of Carlton A. Shively, 27 P-H Tax Ct. Mem. 833 (1958).

${ }^{5}$ Commissioner v. Estate of Shively, 276 F.2d 372 (2d Cir. 1960).

${ }^{8}$ INT. REv. CODE OF I954, § $2053(\mathrm{a})$.

7 "The amounts that may be deducted as claims against a decedent's estate are such
} 
A 1929 Supreme Court decision, Ithaca Trust Co. v. United States, ${ }^{8}$ established the rule that subsequent events are not to be considered in the valuation of remainders willed to charity. Since the tax is upon the transfer of property, it was deemed payable upon conditions as they existed at the time of the transfer. ${ }^{\circ}$ It was concluded, therefore, that the value of a remainder to charity must be estimated as of the decedent's death, ${ }^{10}$ without regard to subsequent events. ${ }^{11}$ It is arguable that this conclusion was a mistaken one, since the date of death is only determinative of what interests pass-and not determinative of the problem of how such interests are to be valued. However, the rule of the Ithaca case has been further buttressed by statutory provisions relating

only as represent personal obligations of the decedent existing at the time of his death, whether or not then matured, and interest thereon which had accrued at the time of death. ... Only claims enforceable against the decedent's estate may be deducted." Treas. Reg. \$ 20.2053-4 (x958). See also Lowndes \& KRAMER, FEDERAL EsTATE AND GiF'T Taxes 337 (1956); 4 Mertens, Law of Federal Gift and Estate Taxation $\$ 26.39$ (1959).

279 U.S. I5 (1929). The Court held that the value of a remainder to charity must be computed by actuarial computation of the life tenant's life expectancy, without regard for the fact that the life tenant died unexpectedly less than 6 months after the testator's death.

"Moreover, no deduction is allowed where there is more than a "negligible" chance, at the testator's death, that the charity will not take-even though the contingency later occurs which vests the property in the charity. See Commissioner v. Sternberger's Estate, 348 U.S. 187 (1955); Estate of Wilbur L. Jack, r6 P-H Tax Ct. Mem. 247 (x947); Treas, Reg. \$20.2055-2(b) (1958).

${ }^{10}$ See First Trust Co. of St. Paul State Bank v. Reynolds, 137 F.2d 518 (8th Cir. r 943); Springfield Safe Deposit \& Trust Co. v. Hassett, 43 F. Supp. 4or (D. Mass. r942); Estate of Charles A. Brooks, 27 T.C. 295 (1956). See generally I MERTENs, Law of Federal Gift and Estate Taxation $\$ 7.01$ (1959).

${ }^{11}$ See Estate of Irma E. Green, 22 T.C. 728 (1954). The future affects present value only to the extent that it is reasonably in contemplation. All values depend "Iargely on more or less certain prophecies of the future; and the value is no less real at that time if later the prophecy turns out false than when it comes out true." Ithaca Trust Co. v. United States, 279 U.S. I5I, 155 (1929).

At least one case, however, has modified the Ithaca rule so as to permit subsequently discovered evidence to be used to establish the existence at the time of testator's death of a predetermined state of facts then unknown. See Allen v. First Nat'l Bank of Atlanta, $\times 69$ F.2d 221 (5th Cir. 1948) (charitable bequest conditioned upon non-pregnancy of testator's wife at his death; later evidence determined there could be no posthumous child).

A few early decisions held that subsequent events should be considered in valuing charitable deductions. See Herron v. Heiner, 24 F.2d 745 (W.D.Pa. 1927); Union Trust Co. v. Heiner, 19 F.2d 362 (W.D.Pa. 1927) (unjust to use tables to value charitable remainder where life tenant survived testator only 12 hours); Boston Safe Deposit \& Trust Co. v. Nichols, I 8 F.2d 660 (D. Mass. 1927). See also Treas. Reg. $\S 20.2055^{-2}$ (d) (1958) (no deduction for any portion assigned or surrendered by charity pursuant to a compromise settlement). 
to alternate valuation. ${ }^{12}$ Under the alternate valuation method, charitable deductions are to be valued as of the date of death with allowance made for any difference in value as of the alternate valuation date not due to the mere passage of time or to the occurrence or non-occurrence of a contingency. ${ }^{13}$ The fact that Congress does not allow post-death contingencies to be taken into account in valuing charitable deductions under the alternate valuation method dictates a similar result when the estate is valued at the date of death. A contrary conclusion would result in the absurdity of non-consideration of a contingency occurring before the valuation date (when the estate is valued at the alternate valuation date), yet consideration of such contingency occurring after the valuation date (when the estate is valued at the date of death).

The Ithaca rule has not generally been confined to the valuation of charitable remainders but has been extended by some courts to include valuation of the entire estate ${ }^{14}$-including claims against the estate. ${ }^{16}$ The Tax Court's holding in Shively that the claim should have been valued as of decedent's death followed this rule. ${ }^{16}$ While a general rule governing the time of valuation of all portions of the estate would

${ }^{12}$ INT. REv. CODE OF 1954, § 2032.

${ }^{13}$ It is significant that under the alternate valuation method, the occurrence or nonoccurrence of contingencies between the date of death and the alternate valuation date is to be considered in valuing all portions of the estate except marital and charitable deductions. See INT. REv. CODE OF I 954, \$ 2032.

${ }^{14}$ See, e.g., Kasper v. Kellar, 217 F.2d 744 (8th Cir. 1954) (marital deduction); Guggenheim v. Helvering, I 7 F.2d 469 (2d Cir. 194I) (valuing decedent's interest in partnership); Estate of Isaac W. Baldwin, 28 P-H Tax Ct. Mem. 779 (1959); Estate of John P. Hoelzel, 28 T.C. 384 (1957) (computing value of wife's life tenancy in annuity and insurance contracts for purposes of marital deduction); John $H$. Denbigh, 7 T.C. 387 (1946). "Where assets are concerned the Treasury has resolutely denied a corresponding devaluation in the light of subsequent conditions." MONTGOMERY's Federal Taxes-Estates, Trusts \& GifTS 1950-5 I 703 (195I).

${ }^{15}$ See, e.g., Winer v. United States, 153 F. Supp. 94I (S.D.N.Y. 1957); Estate of Joseph Whittman, 2 I P-H Tax Ct. Mem. 584 (1952); W. A. May, 8 T.C. 1099 (1947).

${ }_{10}$ Estate of Carlton A. Shively, 27 P-H Tax Ct. Mem. 833 (1958). Arguably, this result would be equitable inasmuch as present valuation is determined by consideration of all possible future contingencies-i.e., those favoring the taxpayer and those favoring the Commissioner. Neither party is necessarily favored because of the application per se of principles of present valuation.

On the other hand, in the Shively case the consideration of subsequent events could only decrease the amount of the deductible claim. The deduction could not exced $\$ 27,058.30$ (the actuarial value of Mrs. Shively's claim) even if Mrs. Shively had not remarried and had substantially outlived her life expectancy. Yet, her early remarriage was considered reducing the deduction to only $\$ 2,079.96$. Thus only some subsequent events, all favoring the Commissioner, were regarded, others being ignored. 
simplify estate administration, it is believed that the language of the Code signifies a congressional intent to consider subsequent events for some valuation purposes and not for others.

Many courts have given effect to this implied congressional intent by refusing to apply the rule of the Ithaca case to claims against the estate. These courts hold that subsequent events are relevant to the valuation of claims in which the amount of decedent's liability is contingent, disputed, or otherwise uncertain at the time of his death. ${ }^{17}$ The opinions stress the policy argument that "the claims which Congress intended to be deducted were actual ones, not theoretical ones."18 The use of tables, and other makeshift values based on probabilities in the face of absolute certainty in the particular case seems to subvert efforts

${ }^{17}$ See Buck v. Helvering, 73 F.2d 760 (9th Cir. 1934) (no deduction for extinguished claim although the estate's liability had previously been reduced to judgment); Jacobs v. Commissioner, 34 F.2d 233 (8th Cir.), cert. denied, 280 U.S. 603 (1929); Smith v. United States, 16 F. Supp. 397 (D. Mass. 1936), aff'd sub nom. United States v. Nichols, 92 F.2d 704 (Ist Cir. 1937) (liability attached when deceased became a stockholder in bank, but amount not ascertainable or payable until assessment after his death); John Jacobs, 34 B.T.A. 594 (1936) (no deduction allowed where state law granting decedent immunity from claim was passed before the tax return was filed); Percy B. Eckhart, Ex'r., 33 B.T.A. 426 (1935). Cf. Leo Dutcher, 34 T.C. No. 95 (1960) (no deduction for executor's or attorney's fees when after 4 years there was no reasonable expectation that they would be paid). See generally 4 MERTENs, LAW OF FEDERAL GifT \& Estate TAXation $\S 26.45$ (1959).

There must be a reasonable right to the deduction existing at decedent's death; it must rest on more than mere doubt ox an ambiguity. 4 MERTENS, LAw OF FEDERAL GifT \& Estate Taxation \$ 26.4 I (1959).

The executor is under a duty to raise the defenses of the Statute of Frauds, statute of limitations, etc. MontcomerY's FEderal TAXEs-Estates, Trusts \& GifTs 19505 I 7 II (1951). Non-resistance and voluntary payment by the executor is not conclusive proof of deductibility of the claim. Estate of $T$. Handasyd Cabot, 46 B.T.A. 225 (1942). Moreover, no deduction is allowed if the creditor waives or fails to enforce payment. An exception is made in cases in which the claim may be deemed paid through the payment of a legacy at least equal to the value of the claim. Rev. Rul. 60-247, 1960 INT. REv. BuLl. No. 29. See Estate of Annie Feder, 22 T.C. 30 (1954).

Where the claim is subsequently compromised, the deduction is limited to the amount payable under the compromise. See Estate of William P. Metcalf, 7 T.C. 153 (1946), aff'd per currian 6th Cir. May 5, I 947 (unreported); Lucius N. Littauer, Ex'rs., 25 B.T.A. 21 (I93I).

Note, however, that the federal courts will not delegate their fact finding functions to state courts and the decree of a state court cancelling a claim is not held to be conclusive as to its value. II PAul, Federal Estate and Gift TAXation 1237 (1942).

${ }^{18}$ Buck v. Helvering, 73 F.2d 760, 763 (9th Cir. 1934); Jacobs v. Commissioner, 34 F.2d 233, 235 (8th Cir.), cert. denied, 280 U.S. 603 (1929). Cf. John Jacobs, 34 B.T.A. 594 (1936). 
to achieve accuracy in valuation. ${ }^{10}$ An unrealistic valuation based on predictions should be used only when no better evidence is available. ${ }^{20}$

The argument that the deduction should be allowed only for "actual" claims finds strong support in section 2053(c)(2), which limits the amount of the deduction for claims against the estate to the value, at the time of decedent's death, of that property within the gross estate which is subject to the payment of such claims under local law. ${ }^{21}$ The sole exception to this limitation-which allows the deduction of amounts actually paid before the prescribed date for filing the estate tax return ${ }^{22}$-gives added weight to the underlying policy.

Another manifestation of congressional intent to consider subsequent events in claims valuation appears in the fact that section $2053(\mathrm{a}) \mathrm{em}-$ bodies not only claims but also funeral and administration expenses which are computed during the course of the administration of the estate and could not be valued at death. Incorporating these deductions together within a single section of the Code suggests that a similar method of valuation should be applied to all.

${ }^{10}$ Cf. Schiffman v. United States, 5 I F. Supp. 728 (Ct. Cl. 1943).

${ }^{20}$ Cf. Nourse v. Riddell, 143 F. Supp. 759 (S.D. Cal. 1956).

Cases involving the problem of consideration of subsequent events in valuation of claims often contain arguments centering around the ambiguous verb tenses in the phrases, "only claims enforceable against the decedent's estate" [Treas. Reg. $\$ 20.2053-4$ (1958)] and "as are allowable by the laws of the jurisdiction" [Section 2053(a) of the x 954 Code]. However, these phrases cannot be deemed decisive. Allowance by a probate court and actual payment by the estate are not deemed to be prerequisite to the deduction of a claim. See Commissioner v. Strauss, 77 F.2d 40x (7th Cir. 1935); 4 MERTENS, LaW OF FEDERAL GifT \& Estate TaXation I63 (I959). This latter phrase means that the items must be "of the type which would be allowed as deductions if the property were in the probate estate." BITTKER, FEDERAL INCOME, ESTATE AND GifT TAXATION I097 (2d Ed. 1958).

A further factor, inconclusive in itself, favoring the use of subsequent events is found in decisions holding that claims which the decedent's estate has against others are includible in the gross estate even though they arise after decedent's denth. See, e.g., Dur Val's Estate v. Commissioner, I52 F.2d I03 (9th Cir. 1945) (where estate paid indebtedness, the value of deceased guarantor's rights over the solvent co-guarantor and the principal debtor included in his gross estate).

${ }^{21}$ Suppose, for example, that decedent died with $\$ 100,000$ in property subject to claims of creditors, $\$ 75,000$ in life insurance (which is taxable to his estate but immunc from claims of creditors) and debts totaling $\$ \Sigma_{50,000}$. Under $\$ 2053$, the deduction for such debts would be limited to $\$ 100,000$, the value of the property subject to their payment. This provision was enacted as $\$ 405$ of the Revenue Act of 1942. Previously, the total amount of the claims had been deductible, even though there was no property in the estatc out of which the debts could be paid. (1956).

See generally, Lowndes \& Kramer, FEderaI Estate AND GifT TAXES 329-30

${ }_{22}$ This exception applies only to the estates of decedents dying after August I6, 1954. 
The Ithaca and Shively decisions are reconciliable in that both limit the taxpayer's deduction. Such should not be the criterion, however. While a similar result will be reached in the majority of cases arising where the two decisions are applied, results favoring the taxpayer are possible. $^{23}$ The Ithaca decision (valuation at death) should govern all cases valuing charitable deductions; the Shively decision (consideration of subsequent events) should control the valuation of claims agamst estates. ${ }^{24}$

In considering subsequent events in valuing claims against the estate, it is imperative that a uniform cut-off date be established. ${ }^{25}$ Except possibly in the situation involving use of the alternate valuation date, the Code is of no assistance here. The Court of Appeals in Shively holds that events occurring before the estate tax return is filed must be considered. It is questionable, however, whether the date of filing should be conclusive, since this rule would allow the executor to manipulate the amount of the deduction. ${ }^{26}$ A second suggestion, which would lessen objections of administrative inconvenience, would require that

${ }^{23}$ For example, application of the Ithaca rule would perhaps favor the taxpayer where there was a bequest to a charity of an estate per autre vie. Should the measuring life be terminated a few days after the testator's death, such event would not operate to limit the value of the charitable deduction. Thus, the estate would obtain the benefit of the actuarial valuation of the bequest at the time of decedent's death.

On the other hand, where a disputed debt is compromised, giving the creditor a remainder interest in specified property (e.g., the debtor's home subject to a life estate in his wife), application of the Shively rule could favor the taxpayer. Should the life tenant survive the debtor by only a short period of time, this subsequent event would be considered in valuing the claim against the debtor's estate, increasing the deduction therefor.

"s It should be noted, however, that the combination of these two decisions, acting in concert with one another, can create an unjust result. Thus, in Shively if the testator had left property to a charity subject to W's claim for alimony and $W$ had died shortly after $\mathrm{H}$, her death would be considered in limiting the value of the alimony claim to the amount actually paid but would not operate to allow a charitable deduction greater than that actuarily predicted for the bequest to charity. Because of the resulting gap, H's executor would not be able to deduct the total value of the property even though it was, and, indeed, had to be under the terms of the will, used entirely for deductible purposes. Although such a result is inequitable, it is compelled by the decisions.

${ }^{25}$ The Government will not, of course, wait until all contingencies are finally resolved before collecting the tax. But cf. Edward C. Moore, Jr., 2 I B.T.A. 279 (1930) (claim disallowed until its value became ascertained six years after decedent's death).

${ }^{20}$ The executor might seek to file the estate tax return early if there is a possibility of the occurrence of an unfavorable contingency (e.g., termination of a claim against the estate which would limit the amount of the deduction). On the other hand, when the occurrence of the contingency would be favorable to the estate, he might delay the filing of the return. 
claims be valued as of the due date for the filing of the return. ${ }^{27} \mathrm{~A}$ third solution is to consider subsequent events occurring within the running of the statute of limitations. ${ }^{28}$ Such a rule would more nearly accord with related provisions and interpretations. For example, the executor has until that date to compute refunds and administrative expenses. ${ }^{20}$

The Shively decision has directed attention to the present lack of uniformity in estate valuation. The question presented, whether subsequent events should be considered in estate tax valuation, involves conflicting policies. If valuation is accomplished on the basis of mathematical probabilities at the date of death, subsequent events will often make this valuation appear absurd. On the other hand, if subsequent facts are considered, the unexpected occurrence of a contingency may overturn a carefully constructed estate plan, necessarily framed on the basis of probabilities. The weighing of these policies may call for consideration of subsequent events for some purposes and not for others. Enactment of clarifying legislation would provide certainty and eliminate needless litigation in this area of estate administration.

\footnotetext{
${ }^{27}$ The estate tax return is due 15 months after decedent's death, plus allowed time extensions. INT. REV. CODE OF 1954, §§ 6075, 608x.

${ }^{28}$ See INT. REv. CODE OF $1954, \$ 6511$.

${ }^{20}$ Treas. Reg. $\$ \S 20.2053^{-1}$ (b) (3), 20.2053-3(b) (I), 20.2053-3(c)(I) (I958).
} 